\title{
A novel approach for the fastest MPPT tracking algorithm for a PV array fed BLDC motor driven air conditioning system
}

\author{
S.Munisekhar ${ }^{1}$, G.V.Marutheswar ${ }^{2}$, P.Sujatha ${ }^{3}$, K.R.Vadivelu ${ }^{4}$ \\ ${ }^{1,3}$ Department of Electrical and Electronics Engineering, JNTUACEA, India \\ ${ }^{2}$ Department of Electrical and Electronics Engineering, S.V.University, India \\ ${ }^{4}$ Department of Electrical Engineering, RCE, India
}

\begin{tabular}{l} 
Article Info \\
\hline Article history: \\
Received Aug 26, 2019 \\
Revised Oct 28, 2019 \\
Accepted Nov 13, 2019 \\
\hline Keywords: \\
BLDC motor \\
Drive \\
PV array \\
Solar \\
Switching losses \\
\hline
\end{tabular}

\begin{abstract}
The paper presents a modified constant voltage (MACV) maximum power tracking algorithm approach for PV array fed brushless DC (BLDC) motor drive for air conditioning application. The proposed algorithm tracks the power instantaneously for sudden changes in solar radiation. The PV power is fed to Voltage source inverter directly without conventional dc dc converter there by reducing the overall cost and high frequency switching losses and efficiency of the system is improved by reducing number of power conversion stages. The appropriateness of the voltage and current controller for PV fed BLDC motor for cooling applications is verified for dynamic changes of solar radiation. The proposed system is designed and modelled and results are verified using MATLAB/SIMULINK software.
\end{abstract}

Copyright $@ 2020$ Institute of Advanced Engineering and Science. All rights reserved.

\section{Corresponding Author:}

S.Munisekhar,

Department of Electrical and Electronics Engineering,

JNTUA Research Scholar, JNT University,

Ananthapuramu, Andhra Pradesh, India.

Email: munisekhar1980@gmail.com

\section{INTRODUCTION}

Alternative energy sources play a vital role in generating power because they are available in plenty in nature and they are friendly to the environment. The power crisis created unlimited pressure in the nation and also in the world as a whole. Unavailability of conventional fuel resources and specific concern about increasing pollution has certainly led the world towards pollution free alternative sources. If one considers the existing problems solar power generation appears as the sole answer to every problem [1-6]. This is the natural energy source which is a lot helpful and free from producing pollutants in great number, secondly it is freely available in the nature and moreover carbon emission can be marginalized to a greater. The basic element in generation of power in solar system is the photovoltaic cell that transforms sun light into electricity. Actually it is an interconnected cell system as a united one, so the more the area of array the more electricity can be produced [7-10]. In this way a larger production of solar energy reduces the cost of generating electricity and thus low cost energy can be supplied for developing countries like India it is a lot useful [11-14].

According to some studies, the tracking of Maximum power point tracking was done in many ways to overcome the drawbacks of solar energy. In the paper entitled Performance assessment, in terms of ripples and power, of conventional and interleaved converter DC-DC with coupled and independent inductors dedicated to photovoltaic installations proposed two topologies i.e conventional boost converter and interleaved boost converter and it was found that interleaved boost converter has good and high power quality and ripples was reduced [15-17]. The optical reflectors for a PV panel adapted by MPPT control improved the light intensity on solar panels by increasing the power output and effeciency and reducing the 
current ripples by boost converter topology [18]. Different algorithms like perturb and observe, current perturbation algorithm (CPA) with a variable perturbation step, fuzzy logic control of MPPT, fractional short circuit current algorithm (FSCC)was proposed to track the maximum power point by improving the effieciency, faster response and reduce steady state oscillations [19-22]. In this paper we propose novel and adaptive voltage reference MPPT tracking algorithm and Lower cost and higher efficient topology without conventional DC-DC converters. The problems listed by conventional algorithms are overcome by proposed algorithm.

\section{RESEARCH METHOD}

The Proposed system for PV array fed air conditioning system is as shown Figure 1. The solar energy generated by photovoltaic modules are is fed to bldc motor driven air conditioning compresser through voltage source inverter. The voltage to the inverter is maintained constant by dc link capacitor [23-24]. The gate pulses to the vsi inverter is generated by voltage and current controllers. The solar voltage and current is given to adaptive voltage reference MPPT algorithm which in turn generates voltage reference to the voltage controller. The dc link current is compared with reference current and generates gate pulses to the voltage source inverter.

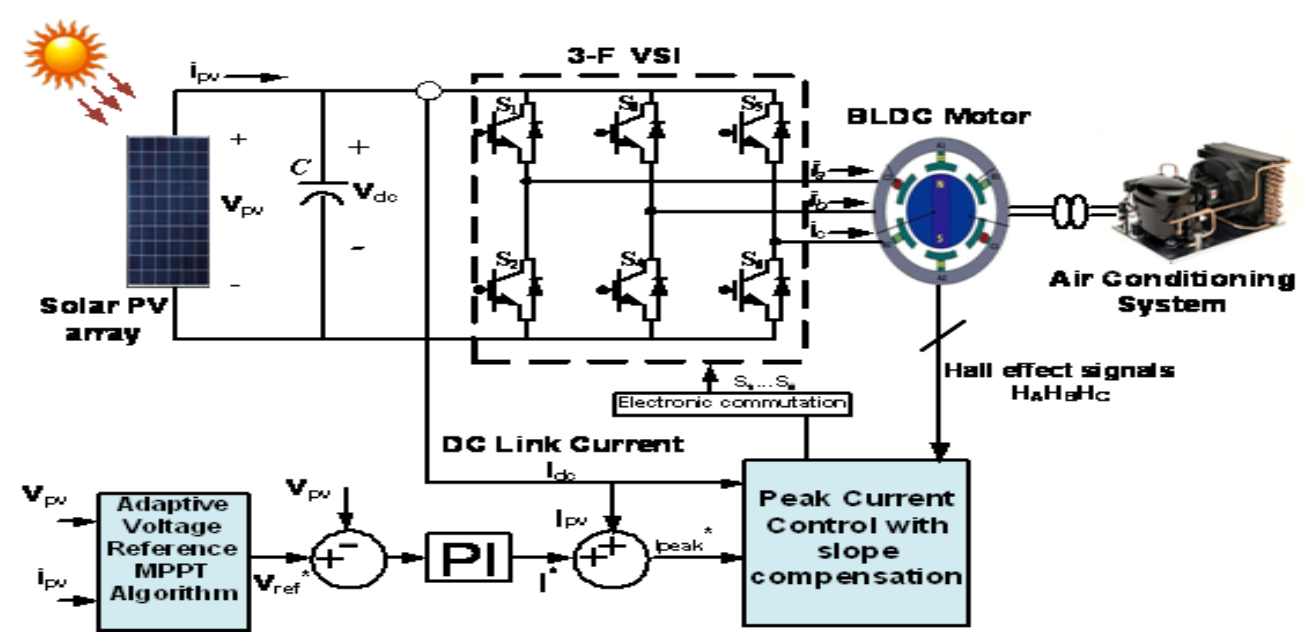

Figure 1. Schematic diagram of solar PV connected with air conditioning system

\subsection{Mathematical Model of Solar Cell}

When sunlight falls on the solar cell it produces dc electricity power. The dc electricity power is a function of load current, temperature and solar insolation as shown in (1).

$$
\mathrm{P}_{\mathrm{o}}=\mathrm{f} \text { (solar insolation, current, Temperature) }
$$

From (1) it is clear that the power output is directly proportional to temperature, insolation and load current. The intensity of solar insolation is linear with the current output of a Photovoltaic cell. The voltage of the solar cell reduces if the temperature of the solar cell is reduced which is in turn proportional to solar radiation [25]. The total amount of power generated will depend on how much light is incident on the solar panels throught out the day. In Figure 2, the PV cell equivalent circuit is shown which consists of series and shunt resistance $\left(R_{s} \& R_{p}\right)$, a current source $I_{p h}$, and a diode.

The PV module parameters are listed in Table 1 as shown below. To achieve rated power and voltage for air conditioner application 20 moudules are conncected in series i.e rated power $200 \mathrm{~W}$ and rated voltage $360 \mathrm{~V}$.

The photovoltaic cell approached by non linear characteristics as one diode model is given by following equations:

$$
I=I_{\text {Photo }}-I_{0}\left(\exp \frac{q\left(V+I R_{S}\right)}{k T}-1\right)-I_{R_{p}}
$$


$R_{p}=R_{p, \text { dark }} \cdot e^{-\alpha E}$

The PV module voltage and current characteristic are described as

$$
I=I_{\text {Photo }}-I_{0}\left(\exp \frac{q\left(\Sigma V+I R_{S}\right)}{k T}-1\right)-I_{R_{p}}
$$

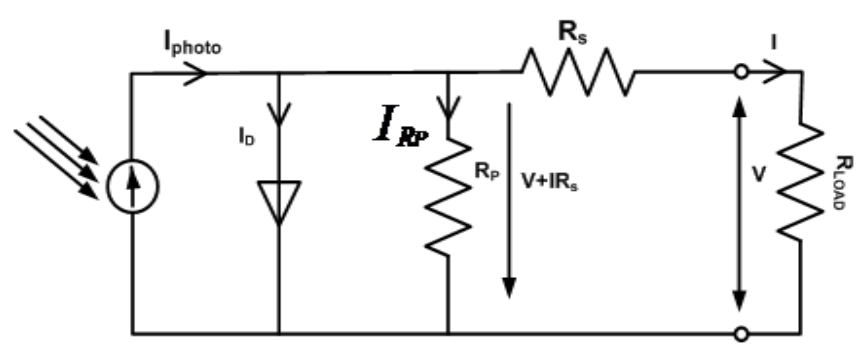

Table 1. Photo Voltaic Module Parameters

\begin{tabular}{lc}
\hline \multicolumn{1}{c}{ Parameters } & Ratings \\
\hline Rated Peak power, $P_{m p p}($ Watt $)$ & 10 \\
Open circuit voltage, $V_{o c}(\mathrm{~V})$ & 21.5 \\
Short circuit current, $I_{s c}(\mathrm{~A})$ & 1.0 \\
Voltage at MPP, $V_{m p p}(\mathrm{~A})$ & 18.1 \\
Current at MPP, $I_{m p p}(\mathrm{~A})$ & 0.75 \\
Series connected cells, $N_{s s}$ & 36 \\
\hline
\end{tabular}

Figure 2. Equivalent circuit of solar cell

\subsection{MPPT Tracking Algorithm for the Proposed Topology}

The solar energy from the pv panel is stored in dc link capacitor. The dc voltage stored in capacitor is converted in to 3 phase ac voltage by voltage source inverter. The new topology as shown in Figure 3 was used for testing the novel mdofied adaptive constant voltage MPPT algorithm. The voltage source inverter acts as buck converter circuit. The capacitor do not allow sudden changes in voltage therefore the voltage to the bldc motor is maintained constant. But to track the mppt power, in the algorithm the voltage is varied as Vref $=$ Vref $+(\mathrm{i} *$ step $)$ i.e with a step value of $0.25 \mathrm{~V}$ when insolation suddenly increases the current from panel is also high, as the capacitor allows sudden changes in current, the extra current is feed forwaded to the bldc motor driven air conditioning system to produce cooling. As shown in Figure 4, when the solar insolation is $500 \mathrm{~W} / \mathrm{m} 2$ the MPP point remains at point A. When insolation suddenly increases to $1000 \mathrm{~W} / \mathrm{m} 2$ the new MPP point to track is point B. Without any control mechanism like constant voltage operation the capacitor starts building the voltage and current instantaneously PV voltage and current. So faster MPPT is achieved as this mechanism works faster with proposed topology.

Peak current with slope compensation is incorpated in the proposed topology to make the proposed algorithm to work faster compared other techniques implemented. The sudden change in PV current is measured and is fed to the current controller in the feed forward path of the BLDC peak current controller. This PV current feed forward technique along with peak current control for BLDC motor also acts to make the MPPT tracking faster.

The flow chart for the MACV MPPT method is shown in Figure 5. As the final step the "modified constant voltage MPPT algorithm" achieves the final MPPT tracking using perturb and observe method, which is rather slow when compared to the first two mechanisms. As the change in voltage is checked if it is greater than zero then $\mathrm{V}_{\text {ref }}=\mathrm{V}_{\text {ref }}+0.25$ otherwise if the condition fails then the reference voltage is decremented as follows $V_{\text {ref }}=V_{\text {ref }}-0$.25. Finally if $V_{\text {ref }}>V_{\text {refmax }}$ if the condition is true then the voltage $V_{\text {ref }}=$ $\mathrm{V}_{\text {refmax }}$.

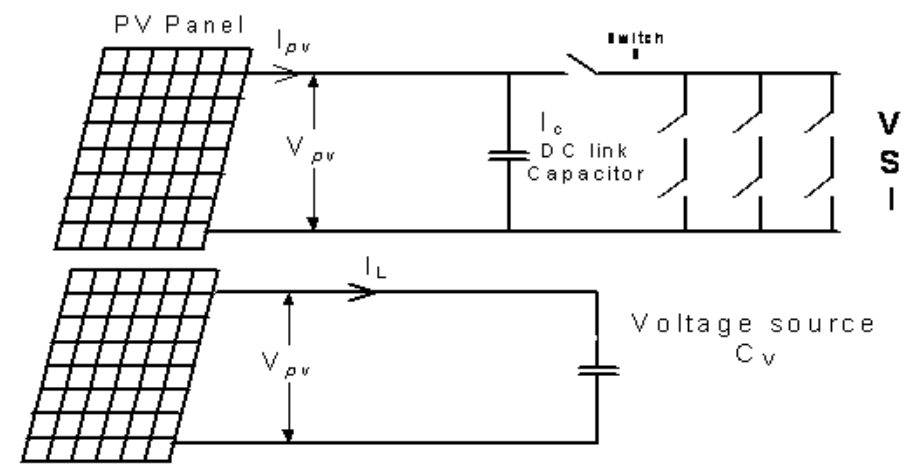

Fiure 3. Tracking of MPPT with buck circuit 


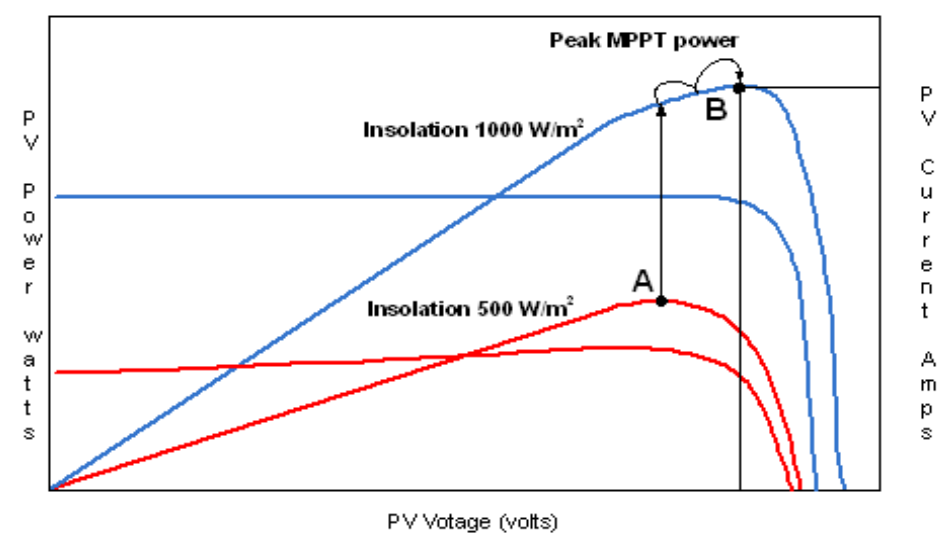

Figure 4. Trajectory path in tracking MPPT power with capacitor

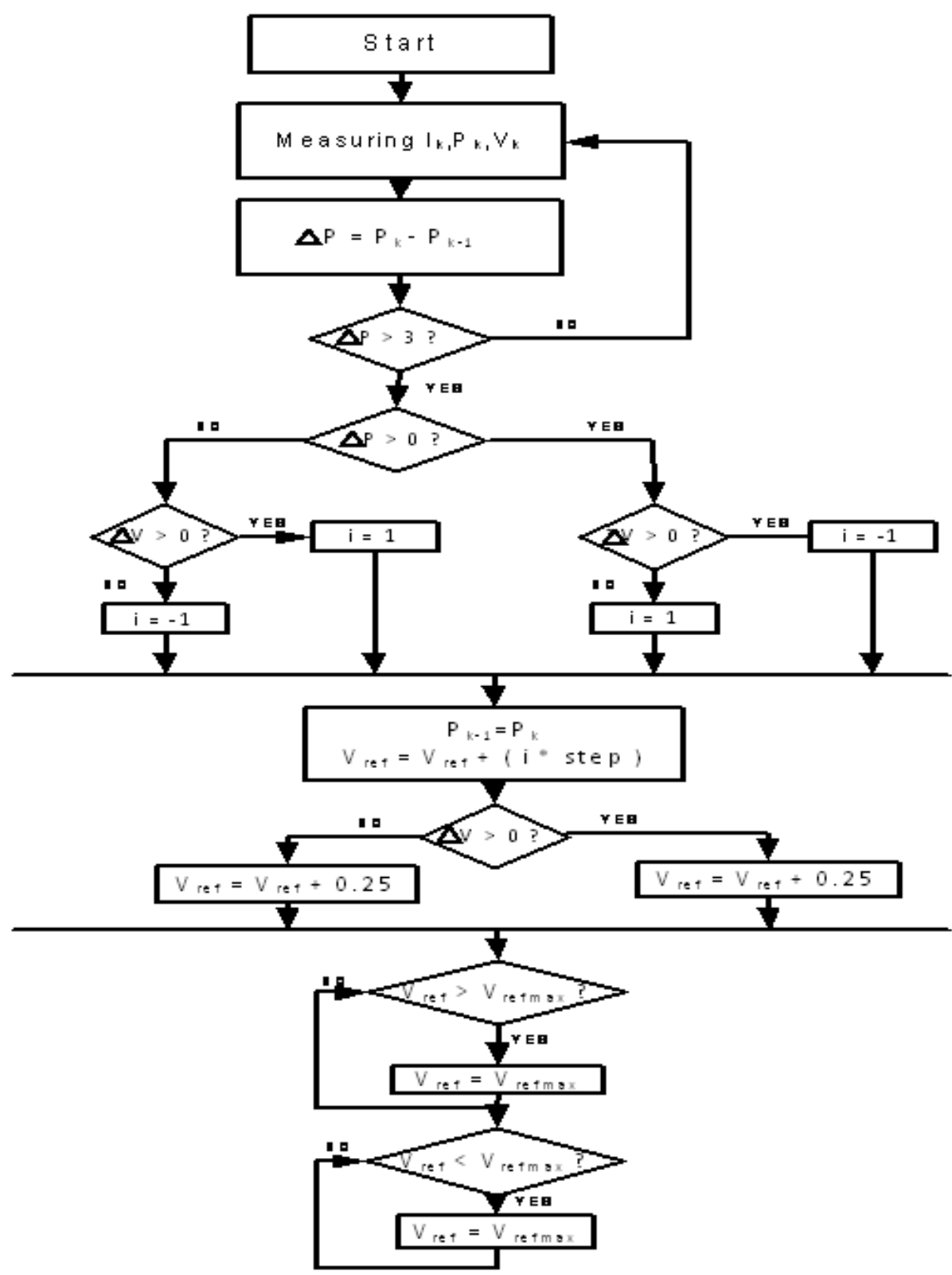

Figure 5. Flow chart of MACV MPPT algorithm 


\section{RESULTS AND ANALYSIS}

An efficient and novel proposed modified adaptive constant voltage MPPT algorithm PV array fed air conditioning system in order to verify and illustrate the advantages was simulated by MALAB/Simulink. In this environment, the proposed system was simulated at $25^{\circ} \mathrm{C}$ temperature and by varying the solar radiation from $500 \mathrm{~W} / \mathrm{m}^{2}$ to $900 \mathrm{~W} / \mathrm{m}^{2}$ over a time interval of $0<\mathrm{t}<1 \mathrm{sec}$, the proposed system was fast and accurate in extracting maximum power from solar panels. The dc link voltage of the capacitor is converter to three phase voltage by proper switching of VSI inverter. The pulses for the VSI inverter is generated by voltage and current controllers. By means modified adaptive constant voltage MPPT algorithm low cost and higher efficieny and faster tracking of MPP point is achieved. The matlab graphs displaying the speed, torque, stator back emf, motor phase current and variation of solar insolation are shown in Figure 6(a), (b), (d), respectively. Figure 6(a), (b) shows the speed and torque of the BLDC motor at $700 \mathrm{~W} / \mathrm{m}^{2}$ solar insolation the values are $100 \mathrm{rad} / \mathrm{s}$ and $1.2 \mathrm{~N}-\mathrm{m}$, and stator back emf in phase a, at $1000 \mathrm{~W} / \mathrm{m}^{2}$ solar insolation and time interval between $0.2<\mathrm{t}<0.4 \mathrm{sec}$ is 110 volts and the stator current in phase a, the between time interval of $0.2<\mathrm{t}<0.4$ $\mathrm{sec}$ for $1000 \mathrm{~W} / \mathrm{m}^{2}$ insolation the value is $0.75 \mathrm{~A}$ and between time interval of $0.4<\mathrm{t}<0.6 \mathrm{sec}$ at $600 \mathrm{~W} / \mathrm{m}^{2}$ solar insolation the value of stator current is $0.5 \mathrm{~A}$.

The simulation results displaying the PV panel current, PV panel Power, Tracking of MPPT power and PV panel voltage are shown in Figure 7(a), (b), (d), (e) respectively. Figure 7(c) shows tracking of MPP for proposed modified adaptive constant voltage MPPT algorithm at different insolation levels for $500 \mathrm{~W} / \mathrm{m}^{2}$, $600 \mathrm{~W} / \mathrm{m}^{2}, 700 \mathrm{~W} / \mathrm{m}^{2}, 800 \mathrm{~W} / \mathrm{m}^{2}$ and $900 \mathrm{~W} / \mathrm{m}^{2}$ the tracking of MPPT power is fast and the actual power is equal to reference power actual power. Figure 7(a), (b), (d) shows the PV panel current, power and voltage and the values are $0.35 \mathrm{~A}, 140 \mathrm{~W}, 360 \mathrm{~V}$ which meets the BLDC motor air conditioning system and these values are observed at $700 \mathrm{~W} / \mathrm{m}^{2}$ solar insolation.

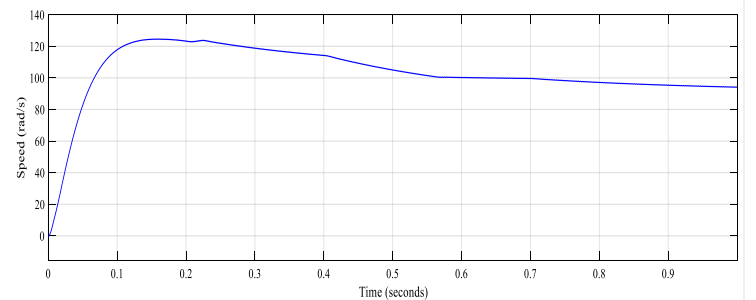

(a)

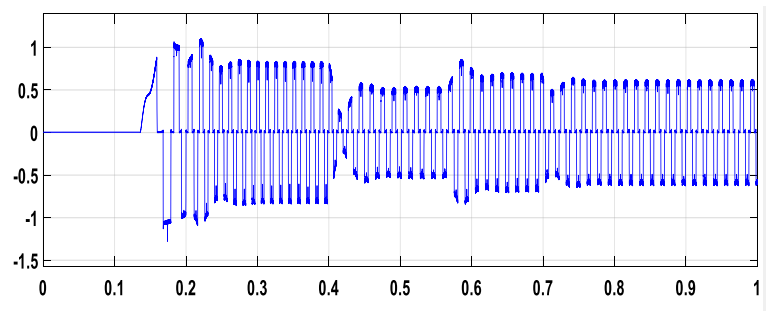

(c)

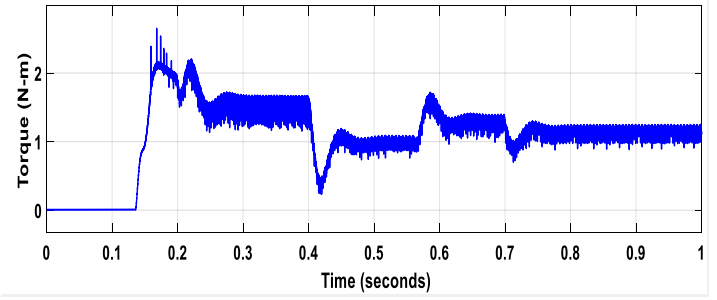

(b)

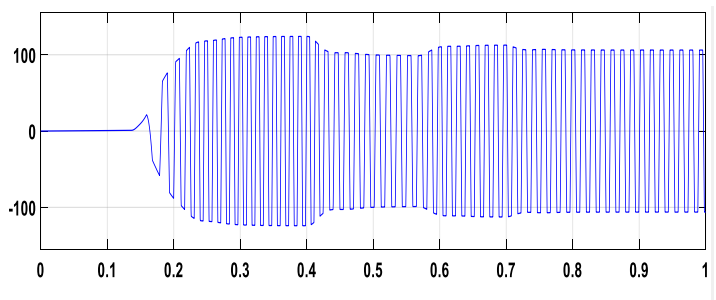

(d)

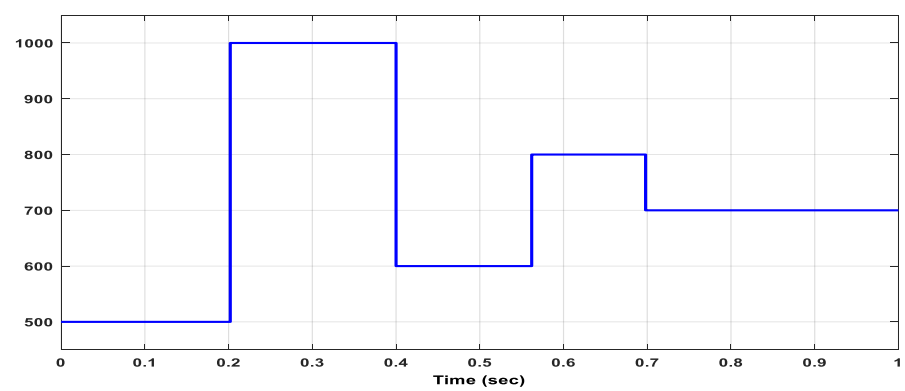

(e)

Figure 6. (a) speed of motor, (b)Torque, (c) stator back emf, (d)Motor phase current,

(e) variation of solar insolation 


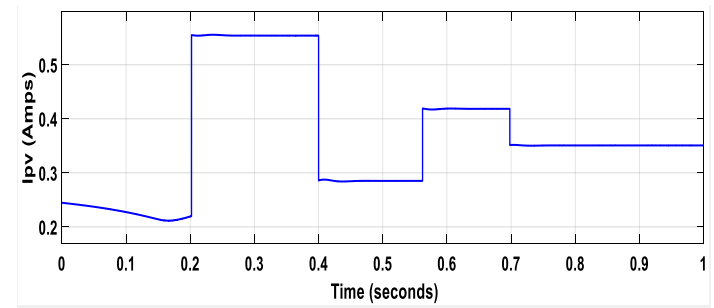

(a)

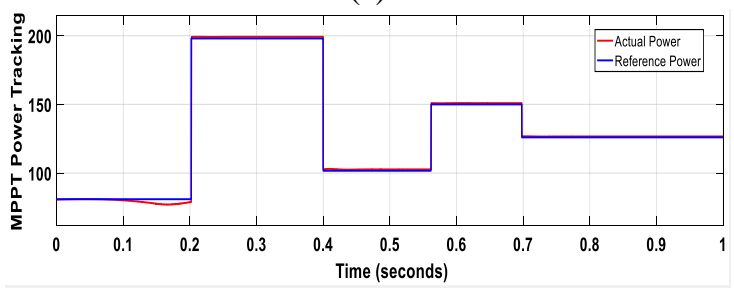

(c)

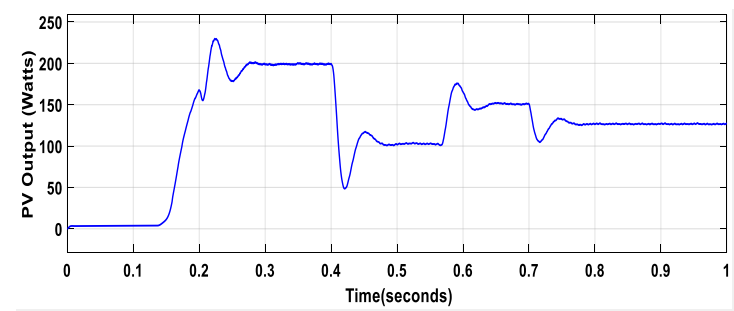

(b)

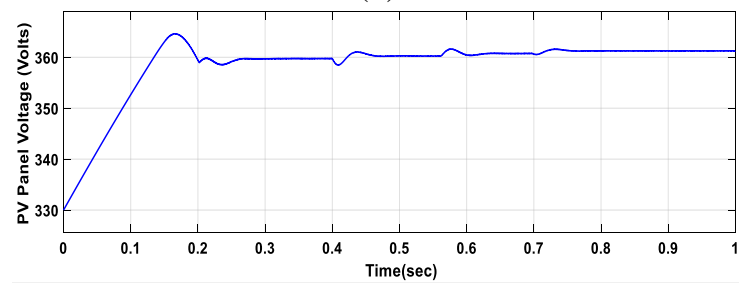

(d)

Figure 7. (a) PV panel current, (b) PV panel Power, (c) Tracking of MPPT power, (d) PV panel voltage

\section{CONCLUSION}

In this paper a solar PV array fed BLDC motor driven air conditioning system with modified adaptive constant mppt algorithm has been proposed. The topology presented without conventional dc dc converter there by reducing overall cost of design and minimizing high frequency switching losses and faster tracking response. The tracking of MPPT power point is fast for dynamic changes in solar radiaton. The simulation results for the proposed topology and MPPT algorithm was good even under dynamic changes of solar insolation.

\section{REFERENCES}

[1] B.Lagssiyer, et al., "Performance assessment, in terms of ripples and power, of conventional and interleaved converter DC-DC with coupled and independent inductors dedicated to photovoltaic installations,"Indonesian Journal of Electrical Engineering and Computer Science, vol. 14, pp. 978-989, May 2019.

[2] Belhadj Mohammed, et al., " Design nd modeling of optical reflectors for a PV panel adapted by MPPT control,"Indonesian Journal of Electrical Engineering and Computer Science, vol. 16, pp. 653-660, Nov 2019.

[3] Hassan Fathabadi, et al., "Novel fast dynamic MPPT (maximum power point tracking) technique with the capability of very high accurate power tracking,"Elsevier journal Energy. Vol. 94, pp. 466-475, Jan. 2016.

[4] Hadjer Bounechba, et al., "Real time simulation of MPPT algorithms for PV energy system," Electrical Power and Energy Systems., Vol. 83, pp. 67-78, Mar. 2016.

[5] Dahlia Canny, Feri Yusivar, "Maximum Power Point Tracking (MPPT) Algorithm Simulation Based on Fuzzy Logic Controller on Solar Cell with Boost Converter," 2nd International Conference on Smart Grid and Smart Cities (ICSGSC)., pp. 117-121, Aug. 2018.

[6] Arash Kalantari, A.Rahmati and A.Abrishamifar, "A Faster Maximum Power Point Tracker Using Peak Current Control," IEEE Symposium on Industrial Electronics and Applications, pp. 117-122, October 4-6, 2009.

[7] Ashwin Chandwani, Abhay Kothari, "Design, Simulation and Implementation of Maximum Power Point Tracking (MPPT) for Solar based Renewable Systems, ” International Conference on Electrical Power and Energy Systems (ICEPES). pp. 539-544, Dec. 2016.

[8] Hiren Patel, Vivek Agarwal, "MATLAB-Based Modeling to Study the Effects of Partial Shading on PV Array Characteristics," IEEE Transactions on Energy Conversion, Vol. 23, pp. 302-310, Mar. 2008.

[9] Raseswari Pradhan, Bidyadhar Subudhi "Design and real-time implementation of a new auto-tuned adaptive MPPT control for a photovoltaic system," Electrical Power and Energy Systems., Vol. 64, pp. 792-803, Jul. 2014.

[10] Neil S. D'Souza, et al., "Peak Current Control Based Maximum Power Point Trackers for Faster Transient Responses, "Canadian Conference on Electrical and Computer Engineering., pp. 659-663, May 2006.

[11] Bouazza Fekkak, et al., "Control of transformerless grid-connected PV system using average models of power electronics converters with MATLAB/Simulink," Solar Energy., Vol. 174, pp. 804-813, Aug. 2018.

[12] Sanjeev Singh, Bhim Singh, "Power Quality Improvement of PMBLDCM Driven Air-conditioner using a SingleStage PFC Boost Bridge Converter, ” 2009 Annual IEEE India Conference., pp. 466-475, Dec. 2009.

[13] R. Gayathri, G.A. Ezhilarasi, "Golden section search based maximum power point tracking strategy fora dual output DC-DC converter," Ain Shams Engineering Journal., Vol. 99, pp. 2617-2630, Dec. 2018.

[14] M. K. Shirazi1, M. Joorabian and A. Sadeghi, “Intelligent P\&O MPPT Algorithm in PV Stand Alone for Faster Transient Response, ” International Journal of Energy Engineering., vol. 5, pp. 74-79, 2015.

[15] S. Yuvarajan and Juline Shoeb, “A Fast and Accurate Maximum Power Point Tracker for PV Systems, " Twenty- 
Third Annual IEEE Applied Power Electronics Conference and Exposition, pp. 167-172, 2008.

[16] G. G. Raja Sekhar1, et al., " An Internal Current Controlled BLDC Motor Drive Supplied with PV Fed High Voltage Gain DC-DC Converter,"Indonesian Journal of Electrical Engineering and Computer Science.,vol. 8,No.2, pp. 1262-1272, Apr 2018.

[17] Lijun ZHANG, et al., "An online maximum power point capturing technique for high-efficiency power generation of solar photovoltaic systems," Journal of Modern Power Systems and Clean Energy., vol. 7,No.2, pp. 357-368, 2019.

[18] Abdelhamid Loukriz, et al., "Design, simulation, and hardware implementation of novel optimum operating point tracker of PV system using adaptive step size," The International Journal of Advanced Manufacturing Technology., vol. 101,No.5, pp. 1671-1680, Apr 2019.

[19] Assia Sellami, et al., "A Novel Auto-Scaling MPPT Algorithm based on Perturb and Observe Method for Photovoltaic Modules under Partial Shading Conditions," Applied Solar Energy., vol. 54, No.3, pp. 149-158, 2018.

[20] Bapayya Naidu Kommula, et al., "A novel scheme for torque ripple minimization of BLDC motor used in solar air conditioner," Electrical Engineering.,vol. 100,No.4, pp. 2473-2483, Dec 2018.

[21] Bhavnesh Kumar, et al., "Review of maximum power point tracking techniques for photovoltaic arrays working under uniform/non-uniform insolation level," International Journal of Renewable Energy Technology. vol. No.4, pp. 439-452, Oct 2018.

[22] Rajanand Patnaik Narasipuram, et al., "Efficiency analysis of maximum power point tracking techniques for photovoltaic systems under variable conditions, " International Journal of Innovative Computing and Applications vol. 9, No.4, pp. 230-240, Oct 2018.

[23] Tha'er O. Sweidan, et al., "Perturbation and observation as MPPT for highly penetrated grid-integrated PV generator considering symmetrical three-phase fault," International Journal of Power and Energy Conversion., vol. 10, No.2, pp. 225-240, Jan 2019.

[24] Saurabh Shukla, et al., "MPPT control technique for solar powered direct torque control of induction motor drive with a robust speed and parameters adaptation scheme for water pumping," IET Renewable Power Generation., vol. 13, No.2, pp. 273-284, Feb 2019.

[25] Amit Kumer Podder, et al., "MPPT methods for solar PV systems: a critical review based on tracking nature," IET Renewable Power Generation., vol.13, No.10, pp. 1615-1632, Jul 2019.

\section{BIOGRAPHIES OF AUTHORS}

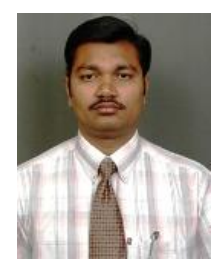

Munisekhar Sadu was born in Tirupathi, India in 1980. He received his B.Tech. degree in electrical engineering from Jawaharlal Nehru Technological University, India in 2002. He is currently working as Associate Professor at the Department of Electrical Engineering, Faculty of Engineering, Siddharth Institute Engineering \& Technology, India in 2015. He is currently working towards the $\mathrm{PhD}$. degree in Electrical Power and Machines Engineering at Department of Electrical and Electronics Engineering, Jawaharlal Nehru Technological University, India. His research interests are in Electrical Machines, Electrical Drives, Power Electronics and renewable energy.

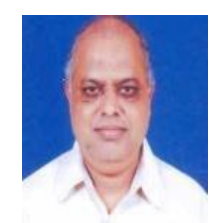

Dr. G.V.Marutheswar was born in Tirupathi, India in 1964. He received the B.Tech. M.Tech. and Ph.D degrees in Electrical and Electronics Engineeing, Instrumentation and Control, Power electronic control of AC Drives from Sri Venkateswara university College of Engineering, India in 1985, 1990 and 2009, respectively. He is currently an professor and HOD at the Department of Electrical and Electronics Engineeing, Sri Venkateswara university College of Engineering, Tirupati, India. His research interests are in Electrical Machines, Electrical Drives, Power Electronics and renewable energy.

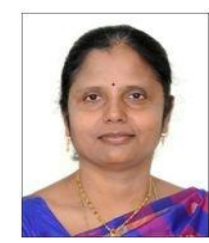

Dr. P. Sujatha presently working as a Professor in Electrical \& Electronics Engineering, JNTUA College of Engineering, Ananthapuramu. She received B. Tech degree in Electrical \& Electronics Engineering from JNTU College of Engineering, Anantapur in 1993, M. Tech degree in Electrical Power Systems from JNTU College of Engineering, Anantapur in 2003 and Ph. D in Electrical Engineering from JNTUA Ananthapuramu in 2012. Her research interests are: Power Systems, Energy Management and Renewable Energy.

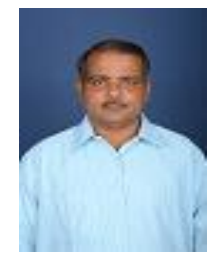

Dr. K.R.Vadivel received the B.Tech, M.Tech. and Ph.D degrees in Electrical and Electronics Engineeing, Power systems, Power systems from Government college of Technology (Autonomous), Bharathiyar, University, Coimbatore, SASTRA University, Tanjore,Tamilnadu. Sri Venkateswara university College of Engineering, India in 1997, 2006 and 2017, respectively. $\mathrm{He}$ is currently an professor at the Department of Electrical and Electronics Engineeing, Ramachandra College of Engineering, Eluru, India. His research interests are in Reactive Power Planning, Power system Voltage Stability, Evolutionary algorithms, Power System operation and control, Power system Optimization and renewable energy sources.

Indonesian J Elec Eng \& Comp Sci, Vol. 18, No. 2, May 2020 : 622 - 628 